\title{
Evaluation of Adapted Wheat Cultivars for Tolerance to Pythium Root Rot
}

\author{
R. W. Higginbotham, Department of Crop and Soil Sciences, Washington State University, Pullman 99164-6420; \\ T. C. Paulitz, USDA-ARS, Root Disease and Biological Control Unit, Pullman, WA 99164-6430; K. G. Campbell, \\ USDA-ARS, Wheat Genetics, Quality, Physiology and Disease Research Unit, Pullman, WA 99164-6430; and \\ K. K. Kidwell, Department of Crop and Soil Sciences, Washington State University, Pullman 99164-6420
}

\begin{abstract}
Higginbotham, R. W., Paulitz, T. C., Campbell, K. G., and Kidwell, K. K. 2004. Evaluation of adapted wheat cultivars for tolerance to Pythium root rot. Plant Dis. 88:1027-1032.

Genetic resistance in wheat (Triticum aestivum) against Pythium species would be an efficient means of control of this major root fungal pathogen, but so far no source has been identified. In addition, no long-term, sustainable options for controlling Pythium root rot are available; therefore, identifying and then incorporating genetic resistance into wheat cultivars would create an ideal method of control for this disease. The objective of this study was to examine the level of tolerance to Pythium root rot among a diverse set of wheat germ plasm collected from all major wheat production regions in the United States. Pythium debaryanum isolate 90136 and P. ultimum isolate 90038, previously identified as the most virulent Pythium isolates on wheat, were used to infest pasteurized soil, which was seeded with wheat genotypes and placed in a growth chamber maintained at a constant $16^{\circ} \mathrm{C}$ with a 12-h photoperiod and ambient humidity. Length of the first leaf and plant height measurements were recorded, and roots were digitally scanned to create computer files that were analyzed using WinRhizo software for length and number of tips. Significant $(P<0.05)$ differences in plant variables were detected among wheat genotypes in the presence of both Pythium species, and a significant $(P<0.0001)$ correlation between plant stunting and root loss was detected. Based on both shoot and root measurements, Caledonia, Chinese Spring, MN97695, and OR942504 appear to be highly susceptible to Pythium root rot, whereas genotypes KS93U161, OH708, and Sunco were the most tolerant to this disease.
\end{abstract}

Due to its wide host range, long-lived oospores, ubiquitous nature, and large number of pathogenic species, Pythium root rot on wheat is extremely difficult to control and has been reported to decrease grain yields by up to $25 \%(1,3,5-7,13,32)$. Nineteen Pythium spp. have been reported on wheat in North America (11). From a sample of 80 wheat fields in eastern Washington, Paulitz and Adams (22) found 46 combinations of 13 different Pythium spp., and nine of these were virulent on wheat (14).

Pythium inoculum levels decrease with stubble burning and soil fumigation (6). Due to its harmful effects on soil quality and societal concerns for air quality, stubble burning is not a viable option for growers, and soil fumigation is impractical for large-scale wheat production $(8,25)$.

Tillage also decreased Pythium inoculum levels in the top $10 \mathrm{~cm}$ of soil (4). For growers using direct-seed cropping systems as a means of soil erosion control,

Corresponding author: T. C. Paulitz

E-mail: paulitz@wsu.edu

Accepted for publication 13 May 2004.

Publication no. D-2004-0712-02R

This article is in the public domain and not copyrightable. It may be freely reprinted with customary crediting of the source. The American Phytopathological Society, 2004. tillage is not an option as a control measure for Pythium root rot. Metalaxyl, a fungicide specific to oomycetes, is often used as a seed treatment for wheat, and it protects the germinating seedling from $P y$ thium infection and damping-off (9). However, metalaxyl provides little or no protection for the growing roots. Biological control of Pythium spp. using bacterial seed treatments also has had limited success, and no bacterial seed treatments for wheat are commercially available $(19,32)$.

Producers have no long-term, sustainable option for controlling Pythium root rot in commercial wheat fields. Incorporating genetic resistance into wheat cultivars would create an ideal, effective, and inexpensive method of control for Pythium root rot. Resistance to Pythium has been found in other crops $(10,17,18,21,26,31)$, but no reports are available that identify wheat germ plasm with tolerance or resistance to Pythium spp.

The objective of this research was to examine, in a controlled growth chamber environment, the variation in susceptibility to Pythium root rot among wheat germ plasm developed in diverse environmental regions in order to identify donors of potential resistance genes useful for cultivar improvement.

\section{MATERIALS AND METHODS}

Wheat breeders from across the United States were asked to submit germ plasm for use in a screening assay for resistance or tolerance to Pythium root rot. Thirty wheat genotypes were included in this evaluation. They were chosen based on genetic diversity and breeder recommendations, and included winter and spring growth habit types and both hard and soft market classes. Eight of these genotypes, including three cultivars from Australia, were chosen based on previous disease screening results for resistance to Rhizoctonia solani and Fusarium pseudograminearum (27-29). Germ plasm used in this study included both experimental breeding lines and commercially released varieties (Table 1), and for simplicity, all germ plasm will be referred to as genotypes. Based on results from a previous virulence assay (14), P. ultimum isolate 90038 and $P$. debaryanum isolate 90136 were chosen for use in disease screening assays.

Inoculum was produced in 2-liter mason jars containing Ritzville silt loam soil collected from the Lind Dryland Research Station of Washington State University, Lind, WA. Soil was amended with $1 \%$ $(\mathrm{wt} / \mathrm{wt})$ ground rolled oats and autoclaved twice (23). Jars were seeded with ten 1$\mathrm{cm}$-square pieces from a 2-week-old potato dextrose agar (PDA) plate culture of each isolate, which was grown at $22^{\circ} \mathrm{C}$. Mason jars were manually shaken to cover agar pieces with soil. Isolates were grown at ambient laboratory temperatures $\left(\sim 22^{\circ} \mathrm{C}\right)$ for 2 weeks, with $10-\mathrm{ml}$ of sterile water added to each jar after 1 week. The inoculum was serially diluted and plated on Pythium selective media (20) to determine inoculum densities. CFU per gram of dry soil was calculated from dilution plate counts.

The screening assays were carried out in tapered plastic tubes $(4 \mathrm{~cm}$ diameter $\times 20.5$ cm long; Cone-tainers; Ray Leach Conetainer, Canby, OR) with drain holes plugged with cotton to prevent soil and moisture loss. Soil used in germ plasm evaluations was pasteurized Thatuna silt loam soil collected from the Plant Pathology Farm of Washington State University, Pullman. The soil was air-dried and mixed with $0.25 \%$ (wt/wt) rolled oats (Old Fashioned Quaker Oats, Chicago, IL). Rolled oats were ground to the consistency of flour with a coffee bean grinder prior to mixing with soil. It was previously determined that ground rolled oats were needed 
as a food base for Pythium to ensure adequate levels of inoculum potential to detect differences between treatments (T. C. Paulitz and R. W. Higginbotham, unpublished data). Soil containing ground rolled oats was then infested with $2 \%$ (wt/wt) pathogen-containing soil suspended in distilled water by manual agitation in plastic tubs. Control treatments consisted of pasteurized soil without added inoculum or ground rolled oats. The Cone-tainers, suspended in racks, were watered with $20 \mathrm{ml}$ of distilled water, and then one seed of each wheat genotype was placed on the soil surface and covered with $10 \mathrm{~cm}^{3}$ of pasteurized Thatuna silt loam soil. In trial 1 , the emergence was poor, so the seeds and plants were removed after 5 days. New seeds were pregerminated for $48 \mathrm{~h}$ on moistened filter paper, placed on the soil surface of the original experiment, and covered with $10 \mathrm{~cm}^{3}$ of pasteurized Thatuna silt loam soil. For trial 2, pregerminated seeds were used at the start of the experiment. Tubes were placed in a growth chamber at a constant temperature of $16^{\circ} \mathrm{C}$ and 12 -h photoperiod with the humidifiers turned off. Each tube was watered with $10 \mathrm{ml}$ of distilled water as needed to prevent desiccation.
To assess repeatability, this experiment was conducted twice. Five replicates for each Pythium isolate by wheat genotype combination were arranged in a randomized complete block design (16). After 14 days, the number of emerged seedlings, plant height (from the soil surface to tip of the longest leaf), and length of the first true leaf were recorded (5). Plants were washed free of soil and debris using a highpressure stream of tap water. Root systems were digitally scanned using a HewlettPackard ScanJet 5370C scanner and saved as TIF files. Root scans were analyzed using WinRhizo software (Regent Instruments Inc., Québec, Canada), which calculated the total root length and number of root tips. Before analysis, scans were manually adjusted to remove shadows, overlapping root segments, and debris (24). Plants that failed to emerge yet still produced root systems were not used in root analysis. To reduce the variability in the adjustment and analysis process, the same person was responsible for all root scans.

Data analysis. Data were analyzed using SAS (Version 8.0; SAS Institute Inc., Cary, NC). Disease reactions of 30 wheat genotypes to the two Pythium isolates were analyzed as a randomized complete block design (16). Analysis of variance was conducted to test for significance of genotype and isolate main effects, as well as to identify any significant interactions among main effects (30). The error mean square was used to test all treatment effects, which were considered fixed (16,30). Least square means were obtained for each treatment. For each genotype, comparisons were made between each inoculated treatment and the noninoculated control treatment using $t$ tests. Differences were considered significant at the 0.05 probability level (30).

For graphical presentation, plant data for each Pythium treatment were expressed as a percentage of the noninoculated control values for each wheat genotype. For this transformation, the least square means for each wheat genotype by isolate within a trial was used to calculate the percent control. To calculate an LSD value for the graphs, analysis of variance was performed on percent control data combined over trials using the trial by genotype by isolate interaction term as the error. Pearson's simple correlation coefficients were deter-

Table 1. Wheat genotypes, their market class and source, that were tested for susceptibility to Pythium debaryanum and P. ultimum in a controlled growth chamber environment

\begin{tabular}{|c|c|c|c|c|}
\hline Wheat line & PI no. ${ }^{a}$ & Pedigree & $\begin{array}{l}\text { Market } \\
\text { class }^{\mathbf{b}}\end{array}$ & Source $^{c}$ \\
\hline Alliance & 573096 & Arkan/Colt//Chisholm sib & HRW & Univ. of Nebraska \\
\hline Ankor & 632275 & Akron/Halt//4* Akron & HRW & Colorado State Univ. \\
\hline Caledonia & 610188 & $\begin{array}{l}\text { Ross Selection/3/(NY5207aB-2B-34)Burt//Genesee/ } \\
\text { CI 12658/4/Genesee }\end{array}$ & SWW & Cornell Univ. \\
\hline Chinese Spring & Cltr 14108 & Selection from field in Missouri by E. R. Sears & HRS & Washington State Univ. \\
\hline Custer & $\mathrm{NA}^{\mathrm{d}}$ & F-29-76/TAM-105//Chisholm & HRW & Oklahoma State Univ. \\
\hline Gala & 422402 & Lawrence/Gabo & NA & Oregon State Univ. \\
\hline Gene & 560129 & Cleo/Pichon//Zenzontli & SWW & Oregon State Univ. \\
\hline Geneva & 505819 & $\begin{array}{l}\text { Ross wheat/3/(NY5207aB-2B-34)Burt//Genesee/ } \\
\text { CI } 12658 / 4 / \text { Genesee }\end{array}$ & SWW & Cornell Univ. \\
\hline Gluyas Early & 382145 & Selection from field of Ward's Prolific & SWS & Oregon State Univ. \\
\hline Hopewell & 595678 & Logan/Hart//32270A/Rousalka/3/TN1685/IA22//6767/216-6-3 & SRW & Ohio State Univ. \\
\hline IL974915 & NA & IL87-2834-1/Glory//MO996552/2/IL90-6364 & SRW & Univ. of Illinois \\
\hline Kaskaskia & 602969 & $\begin{array}{l}\text { IL77-2933(IL70-2255/CI13855//McNair48-23)/IL77-395 } \\
\text { (Arthur/Blueboy//TN1571)//Pike/Caldwell }\end{array}$ & SRW & Univ. of Illinois \\
\hline KS93U104 & NA & TAM107*2//KS8010-1-4-1/TA359 & HRW & USDA-ARS, Manhattan, KS \\
\hline KS93U161 & NA & Century*3/TA2460 & HRW & USDA-ARS, Manhattan, KS \\
\hline KY92C001017 & NA & T63/VA85-54-290 & SRW & Univ. of Kentucky \\
\hline KY93C087666 & NA & ABI $88 * 2451 / K Y 85 C-35-4 / / 2510$ & SRW & Univ. of Kentucky \\
\hline McCormick & NA & $\begin{array}{l}\text { VA92-51-39 (IN71761A4-31-5-48//71-54-147/ } \\
\text { MCN1813)/AL870365 (CK747*2/Amigo) }\end{array}$ & SRW & Virginia Tech. \\
\hline MN97695 & NA & MN92387/SBE0303-23 & HRS & Univ. of Minnesota \\
\hline MN98389 & NA & Oxen/McVey & HRS & Univ. of Minnesota \\
\hline OH708 & NA & IL85-3132-1/Irena//OH449/VA86-54-290 & SRW & Ohio State Univ. \\
\hline OR942504 & NA & Cebeco 148//CNO/INIA//LFN/3/K//PET/RAF/4/ND/P101//AZT & HWW & Oregon State Univ. \\
\hline Overley & NA & U1275-1-4-2/Heyne 'S'//Jagger & HRW & Kansas State Univ. \\
\hline Pat & 631446 & Terral 101 / Pioneer 2548 & SRW & Univ. of Arkansas \\
\hline Roane & 612958 & VA $71-54-147 /$ Coker $68-15 / /$ IN65309C1-18-2-3-2 & SRW & Virginia Tech. \\
\hline Sabbe & 614729 & Corin/3/FL302//Coker 833/Hunter & SRW & Univ. of Arkansas \\
\hline Spillman & 506350 & K73579/Borah & HRS & Washington State Univ. \\
\hline Sunco & NA & Sun9E-27*4/3Ag14//WW15/3/3*Cook & AHW & Oregon State Univ. \\
\hline Trego & 612576 & KS87H325/Rio Blanco & HWW & Kansas State Univ. \\
\hline WA7925 & NA & Spillman/WPB906R//Sunstar II & HRS & Washington State Univ. \\
\hline Wahoo & 619098 & Arapahoe $* 2 /$ Abilene & HRS & Univ. of Nebraska \\
\hline
\end{tabular}

a Plant Introduction.

${ }^{\mathrm{b}} \mathrm{HRW}=$ hard red winter, SRW $=$ soft red winter, SWW = soft white winter, HWW = hard white winter, HRS = hard red spring, SWS = soft white spring, AHW = Australian hard.

${ }^{\mathrm{c}}$ Institution that provided germ plasm.

${ }^{\mathrm{d}} \mathrm{NA}=$ not available. 
mined among the variables total root length, number of root tips, plant height, and length of the first leaf.

The root mean squared error values for each trial were nearly identical, and tests for normality and homogeneity of variances between the two trials were conducted and found to be nonsignificant at the $5 \%$ probability level (16). Therefore, data from the two trials were pooled and analyzed together, except for $P$. debaryanum and plant height, where the trial by pathogen interaction was significant. In addition, emergence of control plants for Chinese Spring was unexplainably low in trial 2; therefore, only Chinese Spring treatments from trial 1 were used in the analysis.

\section{RESULTS}

When trials 1 and 2 were analyzed together, a significant $(P<0.05)$ genotype by trial interaction was detected for plant height. Upon further statistical analysis, it was determined that the interaction was caused by $P$. debaryanum. The source of the interaction involved four genotypes, Geneva, MN98389, OR942504, and WA7925, which were significantly different from the control in only one of the two trials. More seedlings failed to emerge in trial 2 than in trial 1 . Therefore, only data from trial 1 are presented for plant height in the presence of $P$. debaryanum. The interaction between genotype and trial was nonsignificant $(P<0.05)$ for root length, root tip number, and length of the first leaf.

Root length. $P$. debaryanum caused a significant $(P<0.05)$ reduction in total root length compared with the noninoculated controls for genotypes Caledonia, Chinese Spring, MN97695, and OR942504 (Fig. 1A). The largest decreases in total root length caused by $P$. debaryanum occurred in genotypes MN97695 and OR942504, with root lengths measuring 43 and $34 \%$ of the noninoculated controls, respectively. No significant differences in root length in the presence of $P$. debaryanum were observed for most $(\mathrm{n}=26)$ genotypes assayed.

$P$. ultimum caused a significant $(P<$ $0.05)$ reduction in total root length of 17 genotypes and, on average, caused a more severe decrease in root length than $\operatorname{did} P$. debaryanum (Fig. 1B). The mean root length across all genotypes infected with $P$. debaryanum was $105 \mathrm{~cm}$, whereas the mean root length for P. ultimum was 66 $\mathrm{cm}$. The most severe reduction in root length caused by $P$. ultimum occurred in genotypes Ankor, MN97695, and MN98389, with root lengths measuring 33, 27 , and $32 \%$ of the noninoculated controls, respectively. Thirteen genotypes had root lengths that were not significantly different from those of the noninoculated controls. Genotypes OH708, Pat, and Sunco were the most tolerant to infection by $P$. ultimum, with root lengths measuring 73,74 , and $81 \%$ of the noninoculated controls, respectively. Thirteen wheat lines displayed no significant reduction in total root length when grown in soil infested with $P$. debaryanum or P. ultimum. Root lengths of genotypes Caledonia, Chinese Spring, MN97695, and OR942504 were significantly $(P<0.05)$ decreased by both $P$. debaryanum and $P$. ultimum.

Number of root tips. $P$. debaryanum significantly decreased root tip numbers in 12 of the genotypes tested (Fig. 2A). The most severe decrease in root tip number occurred in genotypes Chinese Spring, MN97695, and OR942504, resulting in plants with 31,43 , and $32 \%$ of the root tips of the controls, respectively. Eighteen genotypes had root tip numbers that were not statistically different from the controls. $P$. ultimum caused a significant decrease in the number of root tips for all genotypes except KS93U161 and Sunco (Fig. 2B). The largest decrease in the number of root tips occurred in MN97695, where infected plants had only $20 \%$ of the root tips of the control. The number of root tips was significantly decreased by both $P$. debaryanum and $P$. ultimum for genotypes Ankor, Caledonia, Chinese Spring, Gala, Geneva, Hopewell, IL974915, MN97695,
OR942504, Overley, Pat, and Sabbe. Only two of the 30 genotypes, KS93U161 and Sunco, produced root tip numbers that were not statistically different from the noninoculated controls for both Pythium treatments. A significant $(P<0.0001)$ correlation was detected between the number of root tips and total root length in both trials (Table 2).

Length of the first leaf. When grown in soil infested with $P$. debaryanum, only three wheat genotypes, Chinese Spring, Hopewell, and OR942504, had first leaves that were significantly shorter than the noninoculated controls (Fig. 3A). P. debaryanum caused a 38,38 , and $21 \%$ reduction in length of the first leaf in OR942504, Chinese Spring, and Hopewell, respectively. In contrast, $P$. ultimum caused a significant reduction in first leaf length in 16 genotypes (Fig. 3B). The largest reduction in length of the first leaf occurred in Chinese Spring and Hopewell, which had first leaves that were $50 \%$ of the length of the noninoculated controls. First leaves of Chinese Spring, Hopewell, and OR942504 were significantly stunted by both $P$. debaryanum and $P$. ultimum. Fourteen of the genotypes had first leaf lengths that were not significantly different from the non-

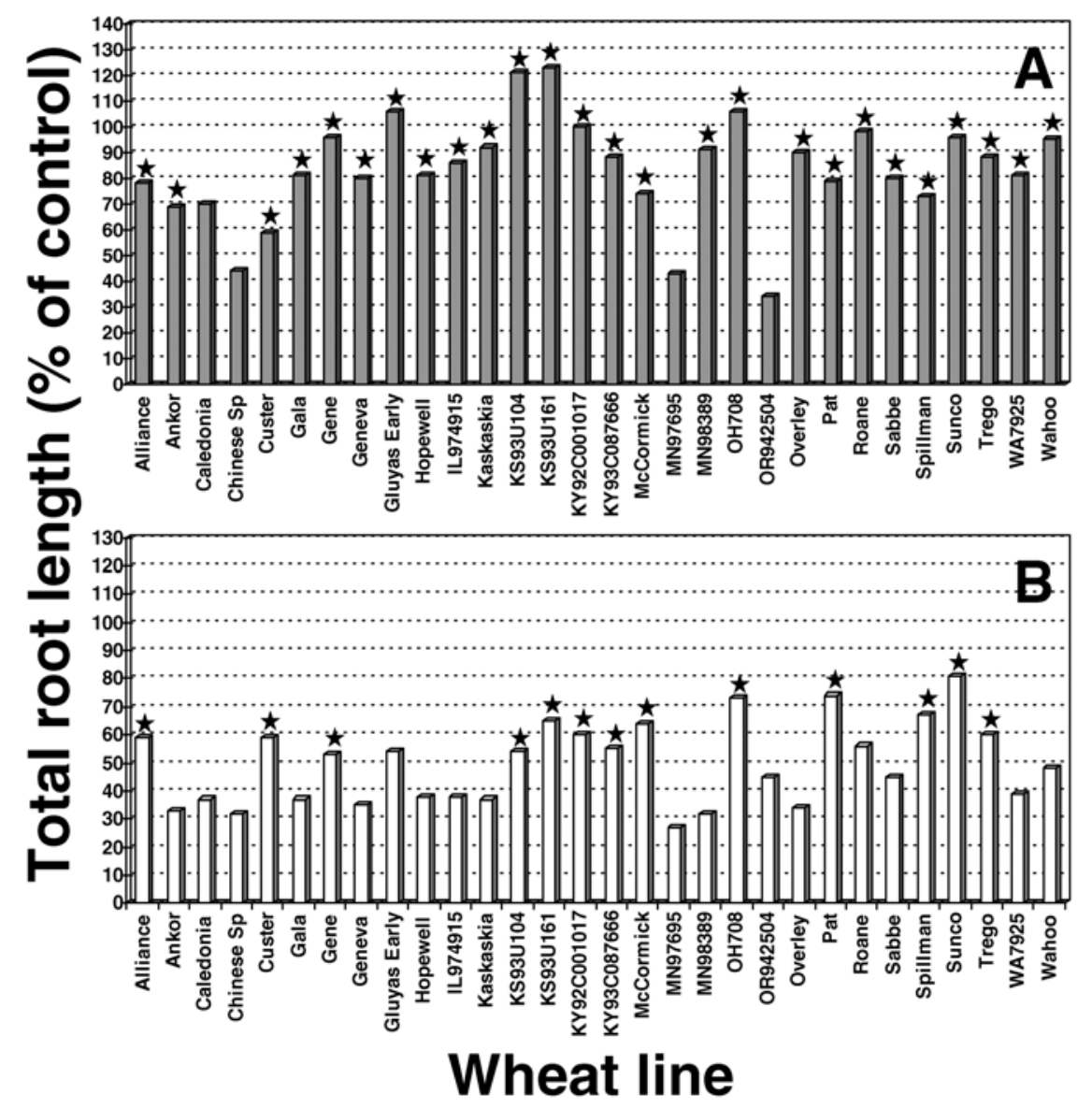

Fig. 1. Effects of Pythium isolates on total root length of wheat genotypes $(\mathbf{A}=P$. debaryanum, $\mathbf{B}=P$. ultimum). Values are expressed as percentage of the controls. The LSD for pairwise comparisons among genotypes at $P=0.05$ was $23 \%$. Stars indicate treatments that did not differ significantly from the noninoculated controls based on analysis of nontransformed data. Data for Chinese Spring are only reported from trial 1 and should not be used for LSD comparisons with other wheat genotypes. 
inoculated controls when grown in the presence of either $P$. debaryanum or $P$. ultimum.

Plant height. $P$. debaryanum caused a significant reduction in plant height compared with the noninoculated controls in eight of the genotypes assayed (Fig. 4A). The largest decrease in plant height was seen in Spillman, which was $68 \%$ shorter than the noninoculated control. Plant heights of OR942504 and Pat were decreased by 46 and $38 \%$, respectively, compared with the noninoculated controls. Plant height was not significantly decreased in 22 of the genotypes when grown in the presence of $P$. debaryanum. Compared with the noninoculated controls, $P$. ultimum significantly decreased the plant height of 22 genotypes (Fig. $4 \mathrm{~B})$. The greatest decrease in plant height occurred in IL974915 and Overley, which had plant heights that were 55 and $50 \%$, respectively, of those from the noninoculated controls. When grown in soil infested with $P$. ultimum, eight genotypes had plant heights that were not significantly different from the controls. Both $P$. debaryanum and $P$. ultimum significantly decreased plant heights of genotypes Ankor, Caledonia, Chinese Spring, Geneva, IL974915, MN97695, MN98389, and Pat. Plant heights of Alliance, Gluyas Early, KS93U104, KS93U161, OH708, and Sunco were not significantly different from the controls in either Pythium treatment.

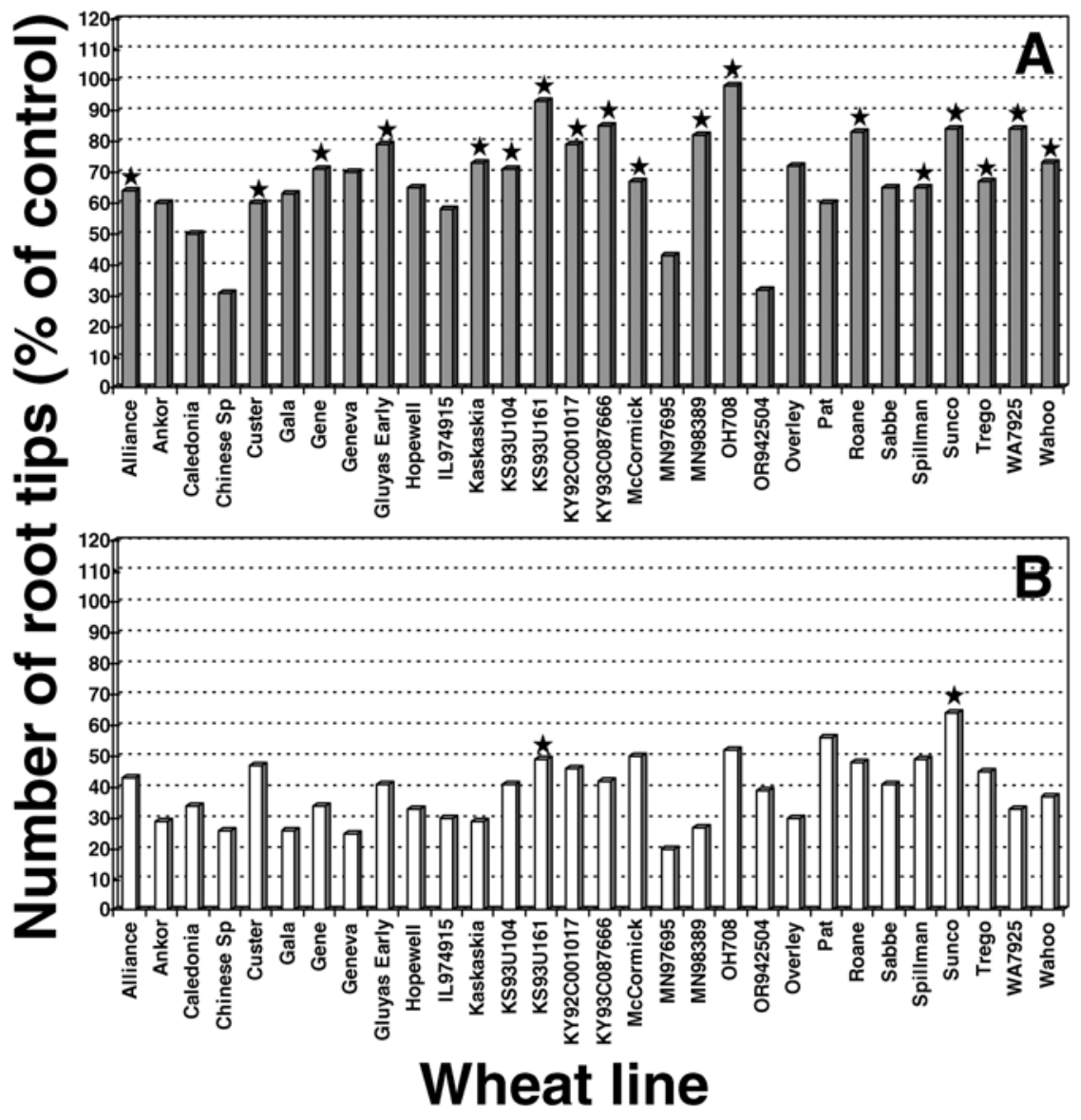

Fig. 2. Effects of Pythium isolates on number of root tips of wheat genotypes $(\mathbf{A}=$ P. debaryanum, $\mathbf{B}$ $=P$. ultimum). Values are expressed as percentage of the controls. The LSD for pairwise comparisons among genotypes at $P=0.05$ was $18 \%$. Stars indicate treatments that did not differ significantly from the noninoculated controls based on analysis of nontransformed data. Data for Chinese Spring are only reported from trial 1 and should not be used for LSD comparisons with other wheat genotypes.
Correlations. Plant height and length of the first leaf were significantly $(P<$ $0.0001)$ correlated (Table 2). Plant height also was significantly $(P<0.05)$ correlated with root length and number of root tips, although the magnitude of the association differed dramatically between trials. In trial 1 , root length and root tips accounted for 46 and $44 \%$ of the variation in plant height, respectively, whereas in trial 2 , root length and root tips accounted for only 4 and $3 \%$, respectively, of the variation in plant height. Fewer plants emerged in trial 2 compared with trial 1 , thereby reducing the number of entries available for correlation analyses, which may have influenced these results. The means (trial $1=16.7 \pm$ $6.4 \mathrm{~cm}$; trial $2=14.1 \pm 3.7 \mathrm{~cm}$ ) and value ranges (trial $1=1.5$ to $27.7 \mathrm{~cm}$; trial $2=$ 2.7 to $24.3 \mathrm{~cm}$ ) for plant height were similar between trials. However, the means for root length (trial $1=93.6 \pm 60.6 \mathrm{~cm}$; trial 2 $=66.0 \pm 52.7 \mathrm{~cm}$ ) and root tip number (trial $1=64.3 \pm 39.9 \mathrm{~cm}$; trial $2=46.6 \pm$ $36.6 \mathrm{~cm}$ ) were noticeably different between trials, which may reflect differences in inoculum potential. There was also a significant correlation between root length and root tip number (0.94 in trial 1 and 0.92 in trial 2).

\section{DISCUSSION}

This is the first report of tolerance of wheat to Pythium spp. based on the variables root length, root tip number, plant height, and first leaf length. As wheat genotypes differed genetically for the variables measured, the only accurate way to compare their susceptibility to Pythium was to calculate data as percentage of the noninoculated controls for each wheat genotype. Variation in virulence of $P$. debaryanum and $P$. ultimum also was detected. For every variable measured, $P$. ultimum caused greater effects on measured variables when compared with the controls than did $P$. debaryanum, which agrees with previous results (14). Similarly, Chamswarng and Cook (2) and Ingram and Cook (15) found P. ultimum to be among the most pathogenic of the $P y$ thium spp. they examined on wheat.

Of the 30 genotypes evaluated in this study, KS93U161 and Sunco appear to have the highest levels of tolerance to $P y$ thium infection when measuring root tip number. As expected, total root length and root tip number were highly correlated. To

Table 2. Simple correlation coefficients $(r)$ between plant height, length of first leaf, total root length, and number of root tips of wheat genotypes pooled across both Pythium species

\begin{tabular}{|c|c|c|c|c|c|c|}
\hline \multirow[b]{3}{*}{ Variables } & \multicolumn{6}{|c|}{ Correlation coefficients $^{a}$} \\
\hline & \multicolumn{3}{|c|}{ Trial 1} & \multicolumn{3}{|c|}{ Trial 2} \\
\hline & Plant height & First leaf length & Root length & Plant height & First leaf length & Root length \\
\hline Number of root tips & 0.68 & 0.56 & 0.94 & 0.17 & 0.21 & 0.92 \\
\hline Root length & 0.66 & 0.58 & & 0.21 & 0.26 & \\
\hline First leaf length & 0.54 & & & 0.65 & & \\
\hline
\end{tabular}

a All correlation values were significant at $P<0.05$. 
measure the number of root tips, manual adjustments must be made throughout the analysis process with WinRhizo root analysis software to account for soil debris and root fragments adhering to the root tissue (24). Even though the WinRhizo software calculates an accurate measurement of root tip numbers, the adjustments that must be made to obtain this measurement are laborious and time-consuming. Since a significant, positive correlation was detected between root tip number and total root length, it may be useful and more efficient to focus on total root length rather than root tips when collecting data on disease effects.

A shortened first leaf is an indication that Pythium isolates have colonized the germinating embryo $(5,6)$. We also found a strong association between plant height and first true leaf length. In general, older seed is more susceptible to embryo infection than fresh seed $(12,13)$. High levels of embryo infection may lead to seedling damping-off (12), and it has been demonstrated that pregermination of wheat seeds prior to planting into Pythium-infested soil increases the percent emergence (13). To ensure that the maximum amount of replications were available for data analysis, seeds of each wheat genotype were pregerminated $48 \mathrm{~h}$ prior to planting. Therefore, seeds were not germinating in the presence of Pythium, thus maximizing emergence. The low number of wheat genotypes for which first leaf lengths significantly differed from the noninoculated controls is most likely due to the pregermination of seeds prior to planting.

Although the proportion of variation in plant height accounted for by root length and root tip numbers differed between trials, this is the first time significant correlations between plant stunting and root loss caused by Pythium have been reported. The washing and scanning of root systems when screening germ plasm for resistance to root pathogens requires manual dexterity and is a time-consuming process that greatly reduces the number of plants that can be screened in a given trial. Given that plant stunting and root loss are correlated, it may be possible to use aboveground data, such as plant height and length of the first leaf, to estimate levels of Pythium infection, which would permit larger numbers of entries to be evaluated in future disease screenings. However, additional research is required to determine the efficacy of using this

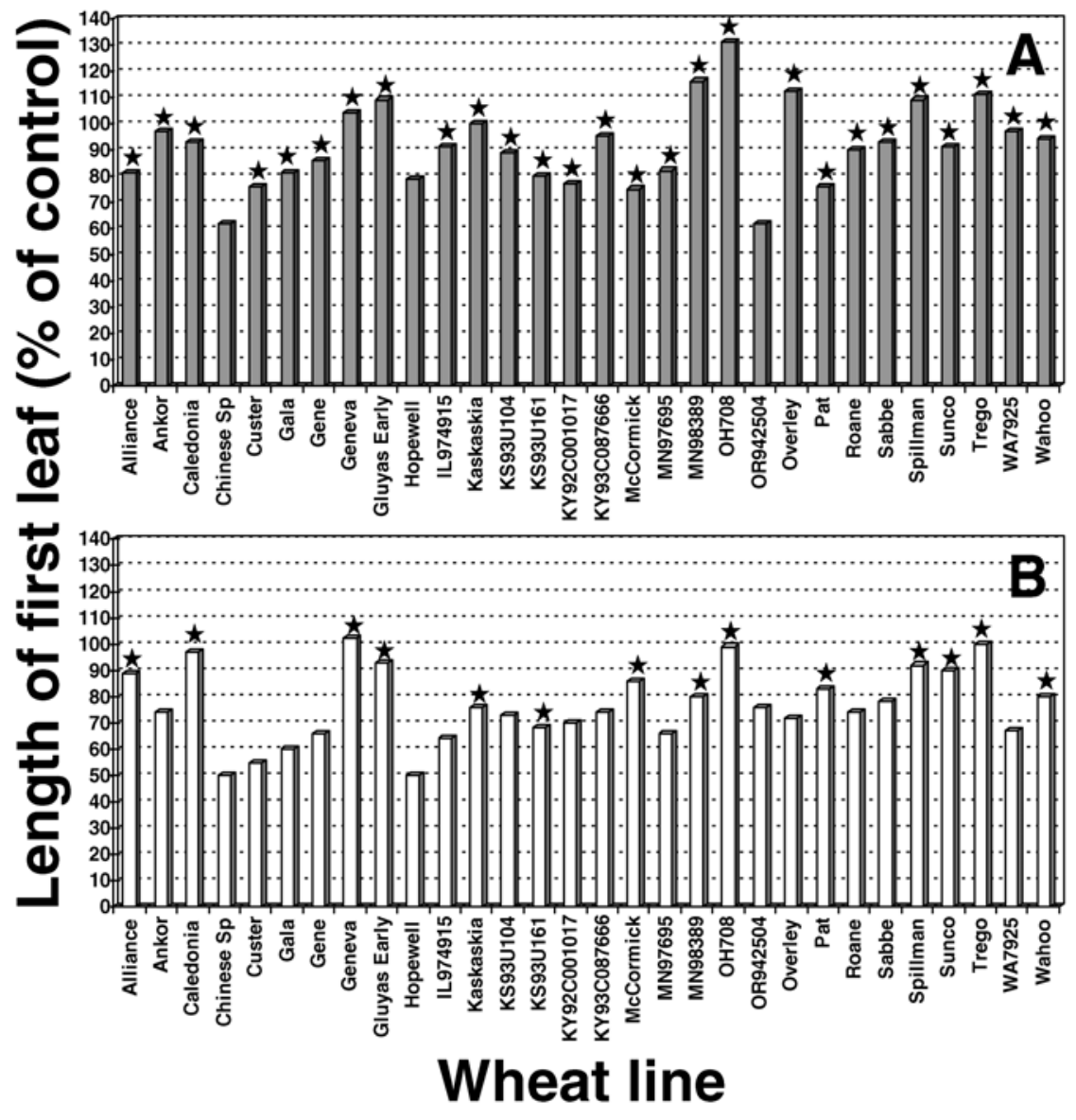

Fig. 3. Effects of Pythium isolates on length of first leaf of wheat genotypes $(\mathbf{A}=P$. debaryanum, $\mathbf{B}=$ P. ultimum). Values are expressed as percentage of the controls. The LSD for pairwise comparisons among genotypes at $P=0.05$ was $18 \%$. Stars indicate treatments that did not differ significantly from the noninoculated controls based on analysis of nontransformed data. Data for Chinese Spring are only reported from trial 1 and should not be used for LSD comparisons with other wheat genotypes. strategy for the assessment of Pythium infection levels.

In general, plants from trial 1 were healthier than plants from trial 2. Seed in trial 1 was first planted directly (no pregermination) into Pythium-infested soil, and as a result, the majority of the seeds failed to emerge. We decided that pregerminating the seed was necessary to prevent the loss of replications due to damping-off and to remove possible variation due to genotype. Entries that emerged were removed from the soil, additional seed was pregerminated, and Cone-tainers were reseeded. This reseeding took place 1 week after the soil was initially infested with Pythium. As a result, inoculum potential in the Cone-tainers may have decreased over 1 week, leading to lower disease symptoms in the first trial.

Our results indicate that variation exists among wheat genotypes in their levels of susceptibility to $P$. debaryanum and $P$. ultimum. No relationship was found between susceptibility to Pythium and market class or growth type of wheat genotypes (data not shown). When grown in soil infested with $P$. debaryanum, 15 genotypes did not differ significantly from the noninoculated controls for any variable measured. Conversely, when grown in soil infested with $P$. ultimum, only two genotypes, KS93U161 and Sunco, were not significantly different from the noninoculated controls for all variables measured. Caledonia, Chinese Spring, MN97695, and OR942504 were the most susceptible and displayed the highest levels of disease when grown in the presence of $P$. debaryanum or $P$. ultimum. Genotypes KS93U161, OH708, and Sunco appear to be the most tolerant to Pythium infection among the wheat genotypes evaluated in this study. Further research will be conducted to determine whether the tolerance detected in these genotypes is heritable, and whether the screening methods used here are associated with tolerance in the field. Genetic mapping populations will be developed in an attempt to identify DNA markers for resistance gene candidates. Data presented here may prove useful when selecting crossing parents for use in wheat variety enhancement.

\footnotetext{
ACKNOWLEDGMENTS

We thank John Gallagher, Jeannie Ellsworth, and Jennifer Freston for their assistance in experimental setup and root scanning. We thank Brett Carver (Oklahoma State University), Clay Sneller (Ohio State University), Alan Fritz (Kansas State University), Mark Sorrells (Cornell University), Robert Bacon (University of Arkansas), Fred Kolb (University of Illinois), Scott Haley (Colorado State University), Dave Van Sanford (University of Kentucky), P. Stephen Baenziger (University of Nebraska-Lincoln), Carl Griffey (Virginia Polytechnic Institute and State University), Jim Anderson (University of Minnesota), Richard Smiley (Oregon State University), C. James Peterson (Oregon State University), and Gina Brown-Guedira (USDAARS, Plant Science and Entomology Research
} 


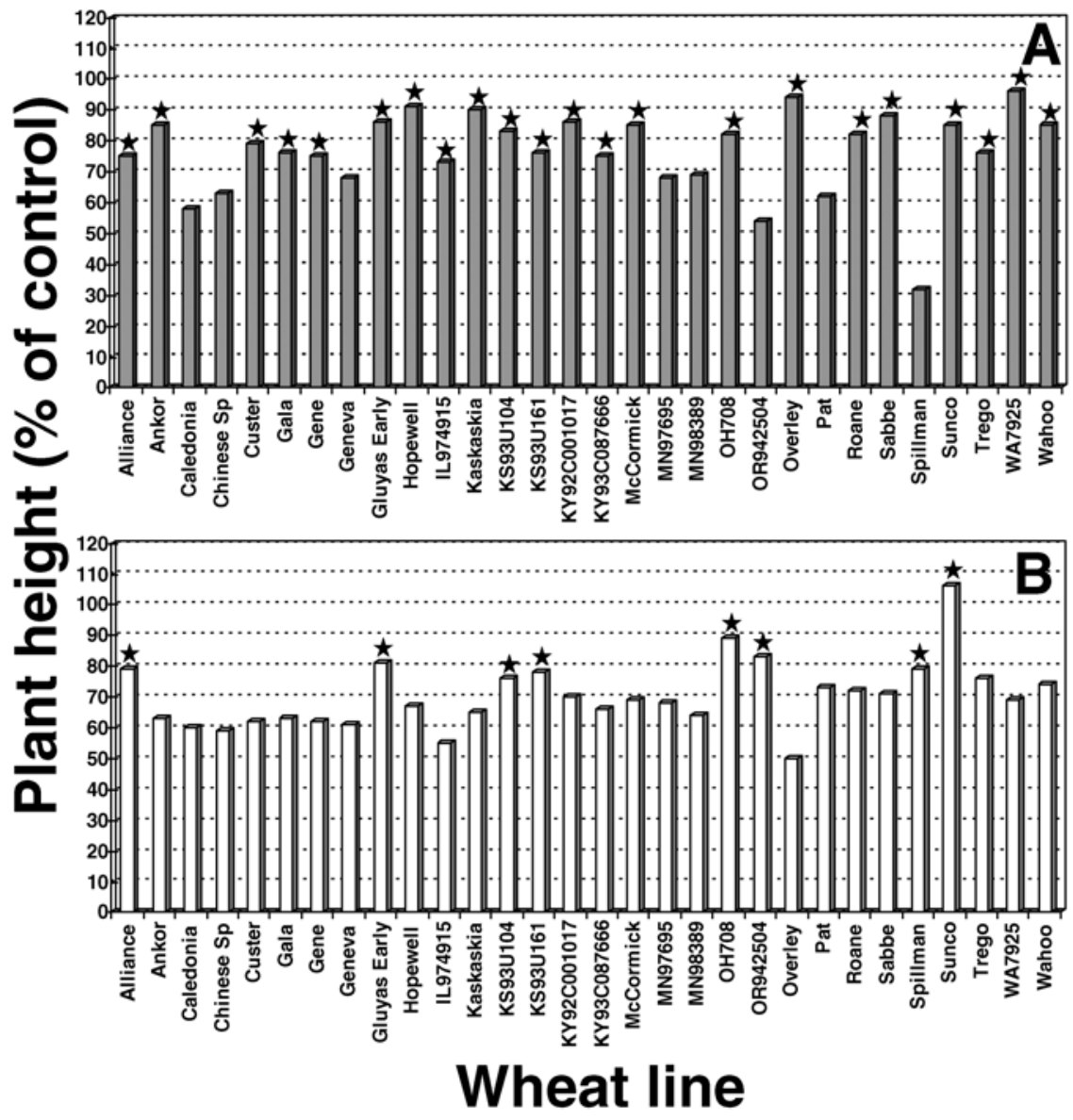

Fig. 4. Effects of Pythium isolates on plant height of wheat genotypes $(\mathbf{A}=P$. debaryanum, $\mathbf{B}=P$. ultimum). Values are expressed as percentage of the controls. The LSD for pairwise comparisons among genotypes at $P=0.05$ was $14 \%$. Stars indicate treatments that did not differ significantly from the noninoculated controls based on analysis of nontransformed data. Data for Chinese Spring are only reported from trial 1 and should not be used for LSD comparisons with other wheat genotypes.

Unit, Kansas State University) for providing the germ plasm used in this research. Funding for this project was provided by the O.A. Vogel Fund (project no. 8334) and the College of Agriculture and Home Economics at Washington State University.

\section{LITERATURE CITED}

1. Chamswarng, C. 1984. Etiology and epidemiology of Pythium root rot of wheat. Ph.D. diss. Washington State University, Pullman.

2. Chamswarng, C., and Cook, R. J. 1985. Identification and comparative pathogenicity of $P y$ thium species from wheat roots and wheatfield soils in the Pacific Northwest. Phytopathology 75:821-827.

3. Cook, R. J. 1992. Wheat root health management and environmental concern. Can. J. Plant Pathol. 14:76-85

4. Cook, R. J., Chamswarng, C., and Tang, W.-H. 1990. Influence of wheat chaff and tillage on Pythium populations in soil and Pythium damage to wheat. Soil Biol. Biochem. 22:939-947.

5. Cook, R. J., and Haglund, W. A. 1982. Pythium root rot: A barrier to yield of Pacific Northwest wheat. Washington State University Agric. Res. Cent. Res. Bull. XB0913.

6. Cook, R. J., Sitton, J. W., and Haglund, W. A. 1987. Influence of soil treatments on growth and yield of wheat and implications for control of Pythium root rot. Phytopathology
77:1192-1198.

7. Cook, R. J., Sitton, J. W., and Waldher, J. T. 1980. Evidence for Pythium as a pathogen of direct-drilled wheat in the Pacific Northwest.

8. Cook, R. J., and Veseth, R. J. 1991. Wheat Health Management. American Phytopathological Society, St. Paul, MN.

9. Cook, R. J., and Zhang, B.-X. 1985. Degrees of sensitivity to metalaxyl within the Pythium spp. pathogenic to wheat in the Pacific Northwest. Plant Dis. 69:686-688.

10. Ewing, E. E. 1959. Factors for resistance to the preemergence damping-off in pea (Pisum sativum) incited by Pythium ultimum Trow. Diss. Abstr. 20:1510

11. Farr, D. F., Bills, G. F., Chamuris, G. P., and Rossman, A. Y. 1989. Fungi on Plants and Plant Products in the United States. American Phytopathological Society, St. Paul, MN.

12. Fukui, R., Campbell, G. S., and Cook, R. J. 1994. Factors influencing the incidence of embryo infection by Pythium spp. during germination of wheat seeds in soils. Phytopathology 84:695-702.

13. Hering, T. F., Cook, R. J., and Tang, W.-h. 1987. Infection of wheat embryos by Pythium species during seed germination and the influence of seed age and soil matric potential. Phytopathology 77:1104-1108.

14. Higginbotham, R. W., Paulitz, T. C., and Plant Dis. 64:102-103.
Kidwell, K. K. 2004. Virulence of Pythium species isolated from wheat fields in eastern Washington. Plant Dis. 88:1021-1026.

15. Ingram, D. M., and Cook, R. J. 1990. Pathogenicity of four Pythium species to wheat, barley, peas and lentils. Plant Pathol. 39:110-117.

16. Kuehl, R. O. 2000. Design of Experiments: Statistical Principles of Research Design and Analysis. 2nd ed. Duxbury Press, Pacific Grove, CA

17. Kulkarni, R. N., and Baskaran, K. 2003. Inheritance of resistance to Pythium dieback in the medicinal plant periwinkle. Plant Breed. 122:184-187.

18. Kumar, J., Kaiser, W. J., and Hannan, R. M 1991. Damping-off resistance in chickpeas. Plant Dis. 75:1244-1245.

19. Milus, E. A., and Rothrock, C. S. 1997. Efficacy of bacterial seed treatments for controlling Pythium root rot of winter wheat. Plant Dis. $81: 180-184$.

20. Mircetich, S. M., and Kraft, J. M. 1973. Efficiency of various selective media in determining Pythium populations in soil. Mycopathol. Mycol. Appl. 50:151-161.

21. Muehlbauer, F. J., and Kraft, J. M. 1978. Effect of pea seed genotype on preemergence damping-off and resistance to Fusarium and Pythium rot. Crop Sci. 18:321-323.

22. Paulitz, T. C., and Adams, K. 2003. Composition and distribution of Pythium communities in wheat fields in eastern Washington State. Phytopathology 93:867-873.

23. Paulitz, T. C., and Baker, R. 1987. Biological control of Pythium damping-off of cucumbers with Pythium nunn: Influence of soil environment and organic amendments. Phytopathology 77:341-346.

24. Paulitz, T. C., Smith, J. D., and Kidwell, K. K. 2003. Virulence of Rhizoctonia oryzae on wheat and barley cultivars from the Pacific Northwest. Plant Dis. 87:51-55.

25. Rasmussen, P., Collins, H., and Smiley, R. W. 1989. Long term management effects on soil productivity and crop yields in semi-arid regions of eastern Oregon. Oreg. State Univ. Columbia Basin Agric. Res. Ctr., Stn. Bull. 675.

26. Salas, B., Secor, G. A., Taylor, R. J., an Gudmestad, N. C. 2003. Assessment of resistance of tubers of potato cultivars to Phytophthora erythroseptica and Pythium ultimum. Plant Dis. 87:91-97.

27. Smiley, R., Whittaker, R., Gourlie, J., Easley, S., Rhinhart, K., Jacobsen, E., Peterson, J., Kidwell, K., and Campbell, K. 2003. Genetic tolerance to Fusarium crown rot of wheat Oreg. State Univ. Agric. Exp. Stn. Spec. Rep. 1047.

28. Smith, J. D., Kidwell, K. K., Evans, M. A., Cook, R. J., and Smiley, R. W. 2003. Assessment of spring wheat genotypes for disease reaction to Rhizoctonia solani AG-8 in controlled environments and direct-seeded field evaluations. Crop Sci. 43:694-700.

29. Smith, J. D., Kidwell, K. K., Evans, M. A., Cook, R. J., and Smiley, R. W. 2003. Evaluation of spring cereal grains and wild Triticum germplasm for resistance to Rhizoctonia solani AG-8. Crop. Sci. 43:701-709.

30. Snedecor, G. W., and Cochran, W. G. 1967. Statistical Methods. 6th ed. Iowa State University, Ames.

31. Tu, J. C., and Park, S. J. 1993. Root-rot resistance in common bean. Can. J. Plant Sci. 73:365-367.

32. Weller, D. M., and Cook, R. J. 1986. Increased growth of wheat by seed treatments with fluorescent pseudomonads, and implications of $P y$ thium control. Can. J. Plant Pathol. 8:328-334. 